\title{
AANTEEKENINGEN OVER HET LANDBOUWRITUEEL IN HET RIJK RAKAWATOE OP MIDDEN-SOEMBA,
}

\author{
van de hand van den volksonderwijzer B. IAHA te \\ Palahona, Rakawatoe, bewerkt en van aanteekeningen \\ voorzien door Dr. C. Nooteboom.
}

Deze aanteekeningen werden op mijn verzoek in 1935 door Iaha opgeschreven uit den mond van een aantal oudere lieden in Rakawatoe, die nog jaarlijks. het hier weergegeven ritueel bij den rijstbouw gebruiken. De schrijver heeft de gegevens verschillende malen nauwkeurig nagegaan en doorgenomen met zijn zegslieden, waardoor hij in staat was onzuiverheden te verbeteren en weglatingen aan te vullen. In zijn ambt als volksonderwijzer was hij in Rakawatoe ondanks zijn jeugd zeer geliefd; hij had het vertrouwen van de bevolking. Om deze reden en om de eerlijkheid en openheid van zijn karakter meen ik in zijn mededeelingen vertrouwen te mogen hebben. Aangezien een Nederlandsche bewerking noodzakelijk de bewoordingen van den schrijver zou vervormen en het stuk in duidelijk Maleisch is gesteld, geef ik er de voorkeur aan dit materiaal te geven zooals het door den schrijver uit den mond zijner zegslieden werd opgeteekend.

Bij Wielenga vinden we in de Macedoniër XIX van 1910 eenige gegevens, die over hetzelfde onderwerp handelen. Vergelijking doet zien, dat er verschillende afwijkingen zijn. De hierbij gepubliceerde Maleische aanteekeningen hebben het voordeel van uitvoerigheid en nauwkeurige wedergave, waaraan het de in vrij populairen vorm gehouden stukken van Wielenga wel eens ontbreekt.

Enkele duidelijke verschrijvingen in het handschrift werden door mij verbeterd. De noten zijn bedoeld als toelichting, waar de tekst door onbekendheid met de ethnografie van Soemba den lezer moeilijkheden zou opleveren.

D1. 98. 


\section{PERI BERKEBOEN DITANAH RAKAWATOE.}

Manoesia soepaja boleh hidoep dengan senang kalau tahoe mentjahari rezekinja, ditanah ini pentjahariannja lain ta'ada hanja berkeboen. Peri berkeboen itoe saja hendak menjatakan itoe:

1. Memboeka tanah.

2. Menanam.

3. Mengetam.

\section{Memboeka tanah.}

Bahagian I kami bahagi lagi atas doea bahagian:

$a$. apa diboeat pada permoelaan; $b$. apa diboeat kemoedian.

a. Pada permoelaan sekali sebeloem tanah jang baroe diboeka (kabanda) 1) haroeslah jang berhendak itoe memanggil seorang imam (amabokol-hamajang) 2). Ketika imam terseboet telah datang diroemahnja, ia menjatakan maksoednja itoe. Sesoedah dinjatakan maksoednja dan sesoedah ia menoendjoekkan tempat mana dan sampai dimana batasnja dan achirnja ia minta soepaja imam tolong dalam hal itoe. Amabokol (imam) itoe djawab ,baik”. Mereka itoe tentoekan bilamana imam itoe pergi bersembahjang pada dewa tanah itoe.

Ketika pergi sembahjang haroes dibawa seekor andjing dan seekor anak ajam oentoek persembahan pada ilah (dewa) tanah itoe. Sesoedah sampai masanja jang soedah ditentoekan, imam terseboet pergi dengan persembahannja tadi pada tempat (tanah) itoe hendak diperkeboenkan. Waktoe sampai ia tjari tempat mana jang baik tempat bersembahjang. Didalam sembahjangnja ia minta soepaja ilah (dewa) itoe berpindah sedikit dari tempat itoe dan biarlah ia berdiam dibatas keboen itoe, soepaja ia boleh bekerdja bersama-sama dengan kami. Sembahjangnja begini boenjinja :

„Ja ilah jang berada pada tempat ini, jaitoe dewa dan dewi tanah ini, jang empoenja tempat ini, sekarang kini saja datang kepadamoe dengan permohonan, soepaja kiranja dewa dan dewi kedoea boleh berpindah sedikit dari tempat ini dan biarlah berdiam dibatas tanah (keboen) itoe. Kami hermohon kiranja bekerdjalah bersama-sama dengan kami. Sebab itoe kami persembahkan seekor anak andjing ini dengan sepotong kawadak (wang) oentoekmoe. Akan tanda jang dewa meloeloeskan permintaankoe, biarlah hati andjing*) (oera dari ajam) itoe menoendjoekkan (baik) menoeroet kehendak kami. Sebab itoe terimalah kiranja permintaankoe."

*) Andjing sendiri ta' disembahjangkan hanja diganti dengan seekor anak ajam. 
Kalau sekiranja oera (tali peroet) anak ajam itoe ta' baik, ditjari lagi didalam oendi (poezvi mowal) 3), apa sebabnja ilah itoe marah. 4) Sebab imam memboeat menoeroet adatnja dengan betoel tentoe oera ajam itoe baik. Sesoedah bersembahjang, imam terseboet ambil segenggam tanah dan dibawanja kebatas tanah (padira tanah). Perboeatan itoe dinamai: „Paloehoe tanah". Waktoe ia (imam itoe) poelang dari bersembahjang ia pergi menjatakan kepada orang jang hendak memboeat keboen itoe, bahwa ia soedah bersembahjang dan ilah (dewa) tanah itoe terima dengan baik.

$b$. Ketika orang tani itoe mendapat chabar baik ia moelai koempoel kawan-kawannja dan djoega orang-orang jang berdekatan dengan dia, soepaja kami moelai memboeka tanah. Ketika hendak moelai kabanda haroes dipotong seekor babi. Imam tadi bersembahjang lagi. Didalam sembahjangnja ia minta soepaja tanah itoe djangan terlaloe berat dan diminta soepaja dewa tanah itoe bekerdja bersama-sama, soepaja djangan sakit dan lelah. Sembahjang itoe begini:

„Ja ilah jang berdiam disini, koeminta padamoe, soepaja makan sirih dan pinang. Kami bermohon padamoe kiranja ja dewa, bekerdjalah bersama-sama dengan kami. Berilah pada kami kekoeatan jang tjoekoep, soepaja kami djangan terlaloe pajah bila kami kabanda. Kami minta djoega kalau kami riboet ilah djangan goesar atau marah pada kami. Kami persembahkan padamoe seekor babi. Kami minta kiranja hati babi terseboet itoe "baik" menoeroet kehendak kami. Terimalah sembahjangkoe!"

Kemoedian babi itoe diboenoeh. Ketika dibakar dan dibelah, hatinja diperiksa. Kalau soedah baik (setoedjoe) menoeroet permintaannja, mereka itoe moelai kabanda. Hati babi dan dagingnja dan djantoengnja diambil sedikit; daging itoe dibakar. Nasi 2 tempoeroeng diambil lagi. Imam terseboet sembahjang lagi boenjinja:

„Ja ilah, saja minta kepadamoe makan apalah hati, djantoeng dan daging ini. Koeminta biarlah bekerdja bersama-sama dengan kami. Djanganlah ada kesoesahan kesakitan berlakoe atas kami. Terimalah permintaan saja."

Kebaktian itoe dinamai: Baha Kahoenga.

Sesoedah itoe orrang-orang moelai kabanda. Kalau beloem habis dibalik tanah itoe pada hari itoe diboeatnja lagi pada lain kali, sehingga habislah tanah itoe diboeka. Kalau soedah diboeka orang jang empoenja keboen itoe memboeat tembok tanah (kamoetoe). Goenanja akan memeleh air, soepaja zat dalam keboen itoe djangan dialirkan olih air hoedjan. Pagar keboen itoe diboeat djoega. 


\section{Menanam.}

Kalau soedah hampir moesim hoedjan, jaitoe kalau goentoer berboenji, ada sembahjang lagi jang dinamai „Hiri tana”. Dipersembahkan seekor anak ajam dan sepotong kawadak. 5) Sembahjang itoe begini boenjinja:

„Ja ilah jang ada pada tempat ini, saja minta engkau makan sirih dan pinang, kepadamoe kami minta biarlah jang boeroek dan jang djahat dan jang pahit dan jang hambar berpindah dari pada tempat ini, sebab itoe saja berikan seekor ajam dan sepotong kawadak bagimoe. Kami minta biarlah oera manoe (tali peroet ajam) itoe jang dipersembahkan padamoe baik menoeroet kehendakkoe. Terimalah permintaankoe!"

Kemoedian ajam itoe diboenoeh dan dibakar dan dibelah. Oeratnja diperiksa. Oeratnja itoe tentoe baik djoega. Sesoedah itoe daging ajam itoe dibakar. Sesoedah itoe daging ajam dan nasi doea tempoeroeng dipersembahkan lagi bagi ilah itoe. Sembahjangnja begini :

„Ja ilah jang ada pada tempat ini, saja minta engkau makan hati dan djantoeng ajam ini dan nasi ini. Koeminta biarlah jang boeroek dan jang djahat dan jang pahit dan jang hambar berpindah dari tempat ini. Dan berpindah pada batas tanah (padira tana). Terimalah permintaankoe!"

Kemoedian imam itoe ambil segenggam dan dibawanja ke „Katoeada woka" 6). Dan lagi diambilnja segoempal dan dibawanja ke „Padira tana” 7). Kemoedian padi, djagoeng dan lain-lain ditanam. Sesoedah tanaman itoe soedah tinggi sedikit ada sembahjang jang dinamai „Pawanding wini” (mengkoeatkan benih). Ketika sembahjang dipersembahkan seekor ajam dan sepotong wang. Sembahjangnja begini :

„Ja ilah jang ada pada tempat ini, saja minta kepadamoe makan sirih dan pinang. Sekarang ini saja datang kepadamoe akan bermohon kiranja tanam-tanaman jang dalam keboen ini, ilah lindoeng dan djagalah siang dan malam. Biarlah tanaman ini mendjadi soeboer sekali. Biarlah batang toemboehan itoe seperti batang teboe dan pisang adanja. Sebab itoe saja datang dengan membawa kepadamoe seekor ajam dan sepetong kawadak. Akan tanda ilah terima permintaankoe, biarlah oera manoe itoe "baik” seperti saja kehendaki. Terimalah permintaankoe!"

Lain daripada sembahjang-sembahjang ini, akan kebaktian jang dilakoekan di kampoeng alias [atas?] Roemah berhala. 8) Waktoe 
kebaktian dipersembahkan seekor babi dan ajam-ajam sebanjak berhala jang berfamilie dengan berhalanja. 9) Dalam hal itoe perloe doea orang toea. Seorang jang mendjadi toekang sembahjang dan jang lain mendjadi pemberi tahoe maksoed kebaktian jang dilakoekan waktoe itoe. Begini dilakoekan:

Pemberi tahoe moelai berseroeh kepada toekang sembahjang katanja: „Hai toekang sembahjang, dengarlah! Bahwa kini telah sampai masanja atau waktoenja perdjandjian kita, pada waktoe goentoer berboenji pertama kali dan soengai bandjir sekali-sekali, jaitoe sampailah masanja atau hari dan boelannja akan makan dan minoem pada berhala menoeroet djandjian kita. Meskipoen tiada dengan sepertinja jaitoe: seperti jang dilakoekan oleh orang jang toea-toea jang meninggal, ma'loemlah ia, bahwa kita ini miskin dan papa djoea adanja. Tetapi sebagai 'adat jang soedah lazim bagi kita, kita haroes datang djoega seberapa kita boleh atau mampoe membawa kepadanja. Dengan sepenoeh-penoeh pengharapan kiranja berhala disini meminta kepada berhala-berhala jang biasa makan sehidangan dengan dia, didjempoetnja soepaja boleh makan sehidangan dengan dia." Soedah itoe imam moelai bersembahjang katanja:

„Makanlah sirih dan pinang hai berhala (dewa dan dewi) jang mendiami roemah ini. Dan djoega koeminta biarlah kiranja berhala panggil akan kawanmoe jang biasa makan sehidangan dengan dikau, meskipoen saja ta' menjeboet namanja masing-masing, koeharap djangan mereka itoe goesar akan dakoe. Sebagai ilah jang ada di Kapoendoek, di Kalamba, di Mondoe, di Hamba Praing, di Mboroe Mbakoe-Lelit Kawoendoet, di Kondoe Hapar-Prai Kememi, tampat engkau mendjelma mendjadi manoesia. 10) Dan djoega jang berada di Woenga (pokok berhala, Oemboe Hili Ndahi dan ramboe Hili Bâba). Dan djoega jang ada di Batapoehoe, di Karoekoe (Oemboe Hamala ramboe Boei); dan di Waimoeroe (Oemboe Toenggoel, Oemboe Kana, Makebar, Mamala) kiranja mereka datang makan sehidangan dengan dikau. Djoega koepohon biarlah jang berdiam di Kopang-Tana Lingoe. Loekoelanggi dija dan Loekoelanggi loeroe tempat padangmoe jang soeboer dan air jang hening (soetji), kiranja mereka itoe datang makan sehidangan dengan dikau. 11) Saja bermohon dengan sepenoeh-penoeh harapan kiranja kamoe memberkatilah oesaha kami dan lindoenglah kami, atau djaoehkanlah dari pada kami mara-bahaja soepaja senang dan sentosalah kami. Akan tanda jang menjatakan berhala ada terima permintaan kami biarlah hati babi jang kami persembahkan bagimoe itoe „baik” serta 
ta' ada tjelanja seperti jang kami soekai. Terimalah permintaankoe!"

Soedah itoe babi tadi diboenoeh. Berhala-berhala jang soedah terseboet diatas masing-masing dipersembahkan baginja seekor ajam. Hal sembahjangnja lain tidak, hanja diminta soepaja ia boleh serta dalam hal mendjagai tanaman dan segala kepoenjaannja. Imam menoentoet djoega oera manoe (tali peroetnja ajam itoe) „baik” akan menjatakan jang berhala itoe soeka dan senang serta soeka djoega menolongnja.

Waktoe babi dan ajam-ajam soedah dibakar dan soedah dibelah, orang toea-toea semoeanja periksa hati atau oera-oera dari ajam tadi. Kebanjakan kalinja ada senang, artinja hati binatang-binatang itoe „baik”, sebab hal kebaktian itoe dilakoekan dengan benar. Sesoedah diperiksa semoeanja daging-daging itoe direboes. Ketika soedah masak, moelai dibagi-bagi daging dan perempoean moelai bagi nasi (sendak) dari perioek. Soedah itoe imam moelai sembahjang lagi boenjinja : „Ja berhala jang mendiami roemah ini dan segala berhala-berhala jang biasa makan sehidangan dengan dikau, koeminta kepada sekaliannja akan datang makan ramai-ramai, jaitoe akan makan hati dan djantoeng babi dan hati dan djantoeng ajam. Biarlah kamoe memberkati kami. Terimalah permintaankoe!"

Soedah itoe segala orang-orang dalam pesta kebaktian itoe moelai makan. Sehabis makan, imam tahadi sembahjang lagi akan menoetoep pesta kebaktian itoe, katanja :

„Ja ilah dan segala jang hadir sekarang ini kamoe soedah habis makan dan minoem. Sebab itoe biarlah kamoe poelang keasalmoe (tempatmoe). Kami minta biarlah kamoe memberkati kami dan djagalah soepaja djangan ada mara-bahaja jang menimpa kami. Terimalah permintaan kami!"

Sesoedah padi moelai berisi ada lagi kebaktian dikeboen. Orang jang mampoe biasa persembahkan seekor babi dan sepotong kawadak. Orang jang ta' mampoe biasa ajam dan kawadak sadja. Dalam kebaktian diminta kepada dewa dan dewi dalam keboen itoe memoelangkan jang dimakan binatang-binatang (tikoes, oelat-oelat dan boeroeng-boeroeng). Biarlah padi seperti ta' ada jang meroesakkan. Hal menoentoet oera manoe atau hati babi itoe, "baik" dan ta'ada tjelanja ta'ketinggalan.

\section{Mengetam.}

Hal mengetam ada empat bahagian: 

a. Pendahoeloean.
b. Mengetam.
c. Mengirik.
d. Menjimpan.

\section{a. Pendahoelocan.}

Sesoedah padi kering belaka dan sebeloem padi itoe diketam semoeanja, haroeslah diambil barang satoe be'ka padi dalam keboen itoe. Padi itoe dibawah kekampoeng. Sampai dikampoeng imam sembahjang kepada berhala. Waktoe itoe dipersembahkan seekor ajam dan sepotong kawadak. Maksoednja akan minta terima kasih akan pendjagaannja pada padinja. Imam bersembahjang jang begini boenjinja :

„Ja ilah jang ada ditempat ini atau jang mendiami roemah ini, koeminta kepadamoe akan datang makan sirih dan pinang, sebab ilah telah menolong dalam hal mendjagai padi dikeboenkoe, sehingga padi itoe telah mendjadi dengan baik dengan tiada koerang apa-apa. Sebab itoe sekarang ini saja membawa persembahan kepadamoe nasi dari hasil keboen ini dan djoega sepotong ajam dan sepotong kawadak bagimoe akan menjatakan terima kasih banjak koeoetjapkan kepadamoe. Kalau sekiranja ilah ada terima serta bersenang hati biarlah oera manoe jang dipersembahkan bagimoe itoe „baik” serta tiada barang tjelanja. Terimalah permintaankoe!"

Ajam terseboet disembelih, laloe dibakar. Soedah itoe ajam itoe dibelah laloe diperiksa oeranja. Banjak kali oeranja itoe baik djoea, sebab memang diboeat dengan atoeran kebaktian. Kalau salah dilakoekan tentoe oera manoe ta' baik. Imam biasa memboeang oendi akan mentjahari mana jang salah. Waktoe nasi dan daging soedah masak, imam terseboet sembahjang lagi, boenjinja begini :

,Ja ilah jang ada pada tempat ini atau jang mendiami roemah ini, koeminta padamoe sekarang ini akan makan hati dan djantoeng ajam ini, sebab ilah telah mempersenangkan hati dengan memberikan berkat atas oesaha kami, jaitoe padi soedah mendjadi dengan baik. Koeminta lagi dengan segenap hatikoe, kiranja berhala memperbanjakkan padikoe itoe. Jang diroesakkan oleh binatang atau tikoes dan boeroeng-boeroeng itoe poelang semoea, soepaja padi itoe diketam berboelan-boelan, bahkan bertahoen-tahoen sehingga namakoe termasjhoer kemana-mana. Terimalah permintaankoe!"

Soedah itoe orang jang hadir semoeanja makan dari barang 
persembahan itoe. Sesoedah makan dan minoem, imam itoe menoetoep sembahjangnja dengan mengatakan:

„Ja ilah sekarang engkau soedah makan dan minoem, biarlah engkau poelang pada tempatmoe. Koeharap kiranja ilah akan memberkati kami. Terimalah permintaankoe!"

Lain dari pada kebaktian dikampoeng tadi, ada lagi kebaktian diroemah keboen. Kebaktian itoe dinamai : ,M e n g o e a t ka n p is a u pengetam padi." Kebaktian itoe disertai dengan persembahan 3 ekor ajam dan 3 potong kawadak. Ajam jang pertama oentoek berhala, jang kedoea oentoek djiwa orang jang soedah meninggal. 12) Ajam jang ketiga oentoek Katoêada Kawindoe (Kental), 13) (Ilah jang mendjagai pekarangan roemah). Dalam kebaktian itoe perloe doea orang jang toea-toea jang pintar. Seorang toekang sembahjang (imam) dan jang lain pemberi tahoe. „Pemberi tahoe berseroeh sebagai orang jang loeloek." Pemberi tahoe berseroeh empat kali dengan soeara njaring. Imam menjahoet empat kali djoega. Soedah itoe pemberi tahoe moelai berkata dengan njaring, katanja : „Hai imam, dengarlah baikbaik” (ampat kali). „Sebab permintaankoe kita soedah diterima oleh berhala kita dengan baik, serta berhala itoe memberkati kita, jaitoe: padi soedah kering bidjinja dan daoennja soedah kemerah-merahan. Karena perdjandjian kita dengan berhala pada permoelaan hoedjan, kita sekarang ini datang mempersembahkan kepada berhala seekor ajam dan sepotong kawadak akan memberi tahoe kepadanja, keesokan harinja itoelah masanja dan waktoenja akan mengetam padi. Biarlah padi itoe diperbanjakkan olehnja, sehingga padi itoe boleh diketam berboelan-boelan lamanja, bahkan bertahoen-tahoen lamanja soepaja nama saja boleh termasjhoer kemana-mana. Dan namakoe dipoedji oleh orang jang mendengarnja."

Soedah itoe imam terseboet teroes bersembahjang katanja:

„Ja ilah jang mendiami roemah ini, koeminta kepadamoe makanlah sirih dan pinang. Oleh sebab pada waktoe hoedjan awal koeminta kepadamoe akan memberkati oesahakoe, jaitoe mendjaga padikoe. Dan sekarang ini ilah telah mendengarkan akan permintaankoe. Sekarang padi telah kering bidjinja dan daoennnja kemerah-merahan. Atas pendjagaan dan perlindoenganmoe, kami persembahkan seekor ajam dan sepotong kawadak. Djoega saja memberi tahoe, bahwa besoklah hari masanja padi itoe diketam. Koeminta kepadamoe biarlah ilah menjertai kami. Biarlah padi diperbanjakkan, sehingga boleh diketam berboelan-boelan, bahkan bertahoen-tahoen. Koeminta padamoe segala padi jang berbatas dengan keboenkoe dan sekelilingnja 
dikoempoelkan dalam keboen ini, soepaja namanja boleh termasjhoer kemana-mana dan namanja dipoedji berkeliling. Akan tanda jang ilah ada terima permintaankoe itoe, biarlah oera manoe ini ,baik" serta ta' ada tjelanja. Terimalah permintaankoe!"

Kemoedian ajam itoe disembelih dan dibakar.

Ajam jang kedoea diambil dan disembahjangkan lagi katanja: .Ja roh-roh orang jang telah meninggal dan jang telah mendjadi ilah jang mendiami oesoe (hoêkoe) dan lata (tâla), koeminta padamoe sekarang ini makan sirih dan pinang, sebal kamoe jang menoendjoekkan peri berkeboen kepada kami, sehingga kami tahoe memboeat keboen, sekarang ini terimalah ajam ini oentock pemakan nasi padamoe; saja minta padamoe mengoempoelkan padi pada sekeliling tempat ini, haraplah kamoe datang bersenang-senang dalam hal ini dengan kami. Akan tanda jang kamoe terima permintankoe biarlah oera manoe ini memberi tanda jang baik kepada kami. Terimalah permintaankoe!"

Soedah itoe ajam itoe disembelih dan dibakar.

Ajam jang ketiga oentoek Katoêada Kawindoe 13). Sembahjangnja begini :

„Ja ilah pendjaga roemah ini, jang mendjagai kami siang dan malam, sekarang ini saja minta kepadamoe makan sirih dan pinang. Saja persembahkan padamoe seekor ajam dan sepotong kawadak akan menjatakan padamøe jang esok hari kami akan mengetam padi. Koeminta kepadamoe akan mengoempoelkan padi-padi sekeliling tempat ini. Haraplah djoega ilah akan djaga benar. soepaja djangan ada jang kehilangan, sehingga padi itoe diketam berboelan-boelan, bahkan bertahoen-tahoen, soepaja namakoe dipoedji dan termasjhoer kemana-mana. Akan tanda jang ilah ada bersenang dan terima permintaankoe biarlah oera ajam itoe „baik”. Terimalah permintaankoe!"

Soedah itoe ajam itoe diambil dan dibakar.

Ajam-ajam tadi dibelah dan diperiksa oeranja. Kebiasaannja baikbaik sadja, sebab diboeat menoeroet adat betoel. Tetapi kalau ada apaapa salah memang ta' baik. Hal itoe disoesoel diperiksa dengan oendi. Kalau soedah dapat mana jang salah, laloe minta ampoen (sembahjang) dengan persembahan anak ajam atau teloer ajam. Dagingdaging ajam itoe direboes. Lazimlah nasi soedah ditanak terlebih dahoeloe. Sesoedah daging-daging itoe masak laloe moelai sendak.

Imam mempersembahkan persembahan makanan : 2 boeah tempae- 
roeng oentoek berhala; 2 boeah tempoeroeng oentoek roh orang-orang mati; 2 boeah tempoeroeng oentoek Katoêada Kawindoe. Hati dan djantoeng ajam-ajam itoe masing-masing disadjikan bahagiannja sendiri-sendiri. Moela-moela di Katoêada Kawindoe jang katanja begini :

„Ja ilah jang mendjaga kami siang dan malam, koeminta padamoe sekarang makan dan minoem dengan senang hati, karena telah disadjikan padamoe hati dan djantoeng ajam ini. Biarlah esok hari ilah datang djagalah soepaja padi-padi djangan hilang. Lagipoen koeminta biarlah ilah pergi koempoelkan padi-padi sekeliling tempat ini. Soepaja itoe banjak sekali, sehingga namakoe termasjhoerlah adanja. Dan jang telah diroesakkan oleh binatang-binatang atau tikoes dan boeroeng-boeroeng biarlah kembali semoea. Terimalah permintaankoe!"

Soedah itoe imam ambil sedikit nasi dan sepotong ketjil hati dan djantoeng ajam laloe ditaroehnja diatas batoe Katoêada itoe. Soedah itse imam naik diroemah. Diroemah (kaheli bokoel) 14) imam itoe sembahjang lagi (4 tempoeroeng nasi dan 2 hati dan djantoeng ajam), katanja: „Ja ilah jang mendiami roemah ini dan roh-roh orang-orang jang mati jang melekap dioesoe dan dilata, toeroenlah kamoe sekarang makan nasi dan djantoeng ajam-ajam ini. Kami haraplah biarlah esok hari kamoe semoea datang menjertai kami dalam waktoe mengetam padi. Kami harap biarlah kamoe mengoempoelkan segala padi dari sekeliling tempat ini. Biarlah jang telah dimakan tikoes dan boeroeng-boeroeng itoe dipoelangkan seperti semoela adanja. Biarlah padi itoe bertambah-tambah banjaknja, sehingga berboelan-boelan diketam, bahkan bertahoen-tahoen lamanja, soepaja nama saja termasjhoer dan dipoedji oleh segala orang jang mendengarnja. Terimalah permintaankoe!"

Soedah itoe imam ambil sedikit nasi dan sedikit hati ajam dan didjatoehkan dibawa kolong roemah. Nasi-nasi tahadi diberikannja kepada anak-anak jang dekat kepadanja. Soedah itoe orang-orang jang ada dalam roemah itoe makan. Sesoedah makan, imam sembahjang lagi, sebagai akan menoetoep kebaktian itoe, katanja:

„Ja ilah dan segala roh orang jang mati jang hadir waktoe ini, saja minta kepadamoe poelang. Haraplah kamoe membantoe kami pada keesokan harinja. Terimalah permintaankoe!"

\section{b. Mengetam.}

Pada waktoe itoe tidak perloe sembahjang lagi. Kalau orang berada misalnja radja-radja biasa potong kewan oentoek pemakan nasi 
orang jang bekerdja. Tetapi orang ketjil ta'oesah diboent sebagai orang-orang jang besar. Sebab ta' perloe lagi. Bagi orang jang mampoe biasanja koempoel orang banjak. Djoega ia mendjempoet orang-orang jang pandai menjanji (loêdoe nggaija). Dalam hal itoe ia memoedji berhalanja djoega dari dahoeloe sampai sekarang. Dalam menjanjinja dimintanja soepaja ilahnja memperbanjakkan padi itoe soepaja diketam berboelan-boelan, bahkan bertahoen-tahoen lamanja, soepaja nama toean keboen itoe dipoedji dan termasjhoer adanja.

Padi jang ditoeai itoe diisi dalam dandak. Kalau menjabit padi ditimboen berkoebik-koebik. Ada besarnja 40 sampai $100 \mathrm{~m}^{3}$. Bergantoeng dari loeasnja keboen. Soedah itoe padi jang ditimboen ditinggalkan sampai akan mengiriknja.

c. Mengirik.

Padi jang ditjeraikan tadi ditoemboek. Toean keboen itoe sebolehbolehnja mentjahari seekor babi. Ketjil besarnja babi itoe tergantoeng dari mampoenja toean keboen itoe. Radja-radja biasa koempoelkan banjak orang, sebab itoe banjak mereka itoe potong kerbau atau koeda atau sapi. Sesoedah sedia segala barang keperloean padi waktoe itoe (beras, babi atau lain, sirih, pinang dan lain-lain) ia moelai mendjempoet orang-orang akan datang menolong dalam hal itoe. Perempoean-perempoean didjempoetnja. Boleh dikatakan segala orang jang mengetam dahoeloe semoeanja didjempoet.

Pada malam persediaan itoe, namanja pawâla karahoe, perempoean atau orang-orang jang tahoe sesoeatoe tjeritera jang bagoes jang dalamnja panâwa, moelai bertjeritera; kebiasaannja menjanji djoega njanjian jang lain (nggaija). Tetapi terdahoeloe dari pada itoe ada kebaktian lagi :

1. Sembahjang dipoesat keboen (poehoewoka).

2. Ditimboenan padi.

3. Katoda kawindoe.

4. Diatas roemah.

1. Kebaktian dipersembahkan seekor ajam dan doea tempat sirih pinang. Bagi orang kaja-kaja atau radja-radja disitoe ditaroeh digantoeng memoeli emas 15) dan kanatar 16). Tetapi orang-orang jang miskin tidak perloe djoega. Baiklah saja tjeriterakan hal sembahjang dari orang jang berada atau radja-radja. Imam bersembahjang begini :

„Ja ilah (dewa) jang berdiam disini, pada tempat poesat keboen 
ini, jang selaloe memandang serta mendjagai isi keboen ini, sehingga ta' kekoerangan apa-apa, koeminta padamoe sekarang ini makan sirih dan pinang, saja memberi tahoe padamoe, bahwa esok hari kami hendak mengirik padi; biarlah padi tinggal banjak sekali, sebagai orang menimba air dari mata air adanja. Sebab itoe saja persembahkan seekor ajam sekarang ini dan djoega sepotong kawadak oentoekmoe. Biarlah padi itoe diirik berboelan-boelan lamanja, sebab telah ada mamoeli dan kanata*) jang menjenangkan hatimoe, sehingga nama saja boleh dipoedji dan termasjhoer kemana-mana adanja. Tanda ilah ada terima biarlah hati (oera manoe) ini menoendjoekkan tanda baik kepada kami. Terimalah permintaankoe!"

Ajam itoe disembelih dan dibakar dan dibelah; dan diperiksa oera manoe itoe. Hati dan djantoeng ajam itoe dibakar. Kemoedian imam minta sediakan doea tempoeroeng nasi. Hati dan djantoeng ajam itoe ditaroeh diatas nasi jang disediakan tahadi. Kemsedian imam bersembahjang lagi katanja:

„Ja ilah jang mendiami tempat ini jang telah menggenapkan permintaankoe pada hoedjan awal, sehingga padi ini telah mendjadi dengan baiklah adanja, koeminta padamoe sekarang makan dan minoem dengan senang, karena telah koesadjikan padamoe nasi dan hati djantoeng ajam ini. Biarlah padi jang diirik pada keesokan harinja itoe bertambah-tambah djoea adanja. Sebab soedah ada mas jang bergantoeng itoe akan penjenangkan hatimoe, soepaja nama toean keboen itoe dipoedji dan termasjhoer adanja. Terimalah permintaankoe!"

Soedah imam ambil nasi dan sedikit hati dan djantoeng ajam itoe diambil dan ditaroehnja diatas batoe tempat sembahjang itoe. Nasi itoe diberikannja kepada anak jang mengikoetnja. Soedah itoe imam itoe sembahjang lagi akan menoetoep kebaktiannja pada tempat itoe. Perkataan sembahjang sama sadja dengan sembahjang diatas.

2. Kebaktian jang kedoea.

Pada waktoe dipersembahkan seekor ajam dan sepotong kawadak djoega digantoeng satoe mamoeli mas dan satoe lakoe loeloeng 17) dan sehelai laoe komboe 18). Dan djoega doea piring sirih pinang. Imam moelai sembahjang katanja:

„Ja dewa padi toea-toea (oehoe koni dan oehoe ndima), koeminta padamoe makan sirih dan pinang, menoeroet djandji kita dan hoedjan awal akan digenapi, sebab itoe saja datang kepadamoe dengan per-

*) dinamai pangatoeng. 
sembahkan seekor ajam, biarlah esok hari perolehan itoe terlaloe banjak, sebagai orang menimba air dari mata air adanja. Soepaja kepoedjianlah namakoe disekeliling tempat dan djoega akan menjenangkan hatimoe koesediakan bagimoe satoe mamoeli mas dan satoe lakoe loeloeng. Dan oentoek dewi koesediakan sehelai saroeng komboe jang bagoes. Koenjatakan padamoe djoega telah koesediakan doea ekor babi. Seekor dikepala tikar pengirik dan jang seekor di Katoda Kawindoe. Akan tanda jang ilah ada terima permintaankoe, koeminta oera manoe ini memberi tanda baik kepadakoe. Terimalah permintaankoe!"

Kemoedian ajam itoe disembelih, ajam itoe dibakar. Sesoedah dibakar ajam itoe dibelah dan dikeloearkan tali peroetnja. Oera manoe itoe diperiksa.Kebiasaannja baik. Hati dan djantoeng ajam itoe dibakar. Sesoedah masak imam minta sediakan doea tempoeroeng nasi. Diatas nasi itoe diletakkan hati dan djantoeng ajam itoe. Soedah itoe imam bersembahjang katanja:

„Ja ilah (dewa dan dewi) padi ini koeminta padamoe akan makan dan minoem, sebab soedah koesediakan nasi dan djantoeng ajam padamoe. Haraplah ilah membantoe seboleh-bolehnja. Terimalah permintaankøe!"

Nasi tadi, dibagi seperti kebiasaannja. Soedah itoe imam toetoep kebaktiannja dengan bersembahjang. Maksoednja seperti diatas.

3. Kebaktian di Katoda kazwindoe.

Kebaktian dilakoekan dengan persembahan seekor ajam dan sepotong kawadak dan satoe piring sirih pinang. Imam bersembahjang begini :

„Ja ilah pendjaga kami siang dan malam, koeminta engkau makan sirih dan pinang. Saja memberi tahoe kepadamoe, bahwa esok hari kami hendak mengirik padi. Haraplah kiranja padi itoe diperbanjakka1 sekali, sehingga diirik berboelan-boelan, bahkan bertahoen-tahoen lamanja, soepaja namakoe masjhoer. Sebab itoe saja membawa kepadamoe seekor ajam. Akan tanda jang ilah ada terima permintaankoe, biarlah oera manoe ini memberi tanda baik kepadakoe. Terimalah permintaankoe!"

Kemoedian ajam itoe disembelih dan dibakar dan dibelah dan diperiksa oera manoe itoe. Hati dan djantoeng itoe dibakar. Imam minta satoe tempoeroeng nasi persembahan. Hati dan djantoeng ajam itoe diletakkan diatas nasi itoe. Soedah itoe imam moelai bersembahjang katanja: ,Ja ilah jang ada pada tempat ini, koeminta padamoe makan nasi, hati dan djantoeng ajam ini. Haraplah kiranja 
kamoe akan datang serta menolong memperbanjakkan padi ini dengan seboleh-bolehnja, soepaja namakoe termasjhoer. Terimalah permintaankoe!"

Nasi itoe diberikannja kepada anak jang ada didekatnja. Soedah itoe toetoep kebaktiannja dengan sembahjang lagi. Maksoednja sama sadja seperti diatas tadi.

4. Kebaktian jang keempat, jaitoe sembahjang didalam roemah. Kebaktian dengan persembahan 4 piring sirih pinang dan 4 ekor ajam dan 4 kawadak, sebab 4 perkara jang diingat: a. oentoek berhala; b. oentoek roh orang-orang jang mati; c. oentoek perkakas jang dipakai misalnja: bakoel-bakoel, dandak-dandak d.1.1.; d. oentoek beras jang akan dipakai.

Pada waktoe ini perloe ada doea orang jang toea-toea (amabakoel). Jang pertama toekang pemberi tahoe dan jang lain toekang sembahjang (imam). Pemberi tahoe berseroeh katanja: „Hai imam pasang telingamoe baik-baik ( 4 kali). Disahoeti oleh imam 4 kali djoega. Pemberi tahoe teroeskan:

„Dari sebab ilah jang mendiami roemah ini (baik loteng baik geladaknja) 19) dan karena esok hari kita akan mengirik padi ini, biarlah kiranja ilah datang membantoe kita, sehingga padi ini dapatlah diirik berboelan-boelan, bahkan bertahoen-tahoen lamanja dan banjaklah loemboeng-loemboeng jang berisi padi ini seperti permintaan kita pada hoedjan awal. Sebab itoe kita persembahkan bagi berhala seekor ajam dan sepotong kawadak, dan bagi roh orang-orang mati kami persembahkan seekor ajam, dan bagi bakoel-bakoel dan dandak dan perkakas jang lain, kami persembahkan seekor ajam dan sepotong kawadak, soepaja djangan [?] banjak isinja; dan bagi beras jang akan dimakan djangan kekoerangan tetapi bertambah-tambah, kami persembahkan seekor ajam baginja. Akan menjatakan bagi kami, bahwa kebaktian kami diterima, biarlah kiranja oera manoe ini memberi tanda jang baik bagi kami".

Imam teroes bersembahjang katanja:

„Ja berhala jang mendiami roemah ini, koeminta sekarang ini makan sirih dan pinang, soepaja kamoe soeroeh hamba-hambamoe akan pergi merampas dan merampok padi-padi itoe ketempat ini dari sekeliling tempat dan koempoelkan padi-padi itoe ketempat ini, soepaja padikoe bertambah-tambah djoea adanja. Dan sebab itoe saja persembahkan bagimoe seekor ajam akan pemakan nasi. Dan djoega bagi roh-roh orang mati, koepersembahkan bagi mereka itoe seekor ajam oentoek mereka itoe soepaja mereka itoe sama-sama membantoe 
dalam hal ini. Dan lagi bakoel-bakoel jang akan dipakai itoe, biarlah djangan [?] terlaloe banjak isinja, kami persembahkan djoega seekor ajam. Dan oentoek beras jang akan dimakan djangan kekoerangan melainkan bertambah-tambah djoea, soepaja djangan mengadakan maloe kepada perempoean-perempoean jang bekerdja dalam hal itoe. Akan tanda jang ilah terima kebaktian kami, serta bersenang hati didalam hal itoe, koeminta biarlah oera manoe jang dipersembahkan ini memberi tanda jang baik kepada kami. Dan djoega soepaja berhala tahoe esok hari saja menjembelih doea ekor babi. Seekor disembelih dikepala tikar pengirik dan jang lain di Katoda woka. Biarlah kiranja djanganlah ada mara-bahaja jang mengalangi didalam hal itoe. Sehingga segala orang bekerdja dengan senang hati adanja. Terimalah permintaankoe!"

Soedah itoe ajam-ajam itoe disembelih dan dibakar dan dibelahbelah dan diperiksa oera manoe itoe sebagai kebanjakan kali diboeat. Daging-daging ajam itoe direboes. Sesoedah sedia atau dimasak laloe imam minta sediakan empat tempoeroeng nasi. Dan hati dan djantoeng ajam-ajam tadi diletakkan diatas nasi itoe. Soedah itoe imam moelai sembahjang akan persembahkan persembahan makanan dan minoeman bagi berhala itoe katanja:

„Ja ilah dan roh-roh orang mati, koeminta sekarang ini akan kamoe makan dan minoem, karena telah koesadjikan bagi kamoe nasi dan paha dan djantoeng ajam in. Biarlah kamoe membantoe dan menolong seboleh-bolehnja, sehingga namakoe boleh termasjhoer kemana-mana. Terimalah permintaankoe!"

Soedah itoe nasi persembahan tadi dibaginja kepada anak-anak seperti biasa. Sesoedah itoe orang-orang semoea jang ada pada tempat itoe pada waktoe itoe moelai makan. Sesoedah makan dan minoem imam toetoep kebaktiannja dengan bersembahjang. Dan hal itoe diminta berhala poelang ketempatnja, sebab telah habis makan dan minoem adanja.

Seperti jang telah koekatakan jang toean keboen mendjempoet orang-orang jang pandai menjanji tahoe banjak tjeritera, sekarang ini orang-orang terseboet moelai menjanji dan bertjeritera „W Woenda Analaloe". Disertakan soerak dan tertawa (kajaka 20) dan kakala). Kesenangan ini diboeat sampai siang. Setelah siang pagi-pagi sekali, orang jang dioendang oleh toean keboen semoeanja datang. Toean keboen itoe membagi sirih dan pinang. Babi jang diperdjandjikan malamnja tadi, dibawa orang masing-masing kepada tempatnja dipersembahkan. Jaitoe seekor pada Katoda Woka (keboen) dan 
jang seekor dikepala tikar pengirik. Djoega ta' diloepai Katoda Kawindoe dipersembahkan lagi seekor ajam. Atau kalau orang berada dipersembahkan seekor kambing dan satoe piring sirih pinang dan djoega doea potong kawadak. Katanja:

„Makanlah sirih dan pinang hai ilah jang melindoengi kami siang dan malam, sekarang ini saja datang kepadamoe dengan persembahkan seekor kambing dan sepotong kawadak akan menjatakan padamoe, bahwa hari ini padi ini hendak diirik. Jaitoe padi jang dilonggokkan jang sebagai orang jang bertamoe roepanja. Koeminta padamoe kiranja ilah menolong akan menambah padikoe ini dengan merampas segala padi berkeliling tempat ini. Dan bagi ilah pendjaga keloear masoek atau toeroen naik koepersembahkan baginja sepotong kawadak djoega, soepaja iapoen boleh menolong dalam hal ini. Biarlah kiranja perolehankoe terlaloe banjak, sehingga banjak jang memoedji, sehingga namakoepoen termasjhoerlah. Terimalah permintaankoe!"

Kemoedian kambing itoe disembelih, kambing itoe dibakar boeloenja.

Pada Katoda Woka dipersembahkan seekor babi, 4 kawadak, pinang semajang (nggai) dan daoen sirih dan bersama rantingnja seikat. Dan mamoeli lakoeloeloeng,laoe komboe jang ada di katikoe tapoe (kepala tikar) tadi malam dipindahkan pada tempat itoe. Imam moelai bersembahjang katanja:

,Ja ilah, koeminta padamoe sekarang ini makan sirih dan pinang, sebab hari inilah masanja padi ini diirik. Koeminta biarlah padi diperbanjakkan sekali, sehingga diirik berboelan-boelan, bahkan bertahoentahoen adanja, sebagai orang menimba air dari mata air. Sebab itoe saja datang kepadamse dengan persembahkan seekor babi dan sepotong kawadak. Koeminta padamoe akan merampas padi sekeliling tempat ini dan koempoelkan pada tempat ini. Dan sepotong kawadak lagi, koeminta padamoe biarlah djangan ada barang maloe pada toean keboen sebagai kekoerangan nasi d.1.1. Soepaja wadjahnja tinggal berseri-seri adanja, sebagai orang jang poelang dari kemenangan. Dan djoega sepotong lagi bagi dewa jang mendiami tempat ini, soepaja ia djangan goesar atau marah, karena riboetnja orang jang ada disini. Begitoelah saja datang kepadamoe dengan sepenoeh-penoeh pengharapan kiranja padi itoe diperbanjakkan, soepaja namakoe boleh dipoedji berkeliling adanja. Akan tanda ilah ada senang dan dengar permintaankoe, kiranja hati babi ini memberi tanda jang baik kepadakoe. Terimalah permintaankoe!" 
Kebaktian dikepala tikar pengirik.

Dalam hal itoe dipersembahkan seekor babi dan doea potong kawadak. Mamoeli dan kanatar dipoesat keboen dipindahkan ke kepala tikar pengirik. Djoega sirih pinang jang ada disitoe dipindahkan ke kepala tikar. Imam bersembahjang begini :

„Makanlah sirih dan pinang ja ilah jang saja djempoet dan sebab kamoe soedah hadir disini, sebab sekarang ini waktoenja padi jang berlonggokan itoe jang seperti tamoe adanja itoe diirik. Koeminta biarlah padi itoe diperbanjak-banjakkan sangat, sehingga boleh diirik berboelan-boelan, bahkan bertahoen-tahoen adanja. Sebab itoe saja datang kepadamoe dengan persembahkan seekor babi dan sepotong kawadak oentoekmoe dan sepotong kawadak jang lain ini oentoek segala orang jang didjempoet olehkoe djanganlah ada kelemahan melainkan dengan kekoeatan serta dengan gembira jang sangat-sangat sebagai orang poelang dengan kemenangan adanja. Haraplah kiranja ilah terima permintaankoe, biarlah hati babi ini baik serta ta' ada tjelanja. Terimalah permintaankoe!"

Kemoedian babi itoe diboenoeh. Amabokol sama-sama memeriksa hatihati babi jang dipersembahkan tadi. Kalau soedah baik, baharoe orang moelai indjak padi itoe. Jang laki-laki masoek dalam tikar pengirik dan perempoean-perempoean menjanji akan menjenangkan hati orang-orang jang mengirik. Banjak kali orang jang mengirik itoe mengirik menoeroet lagoe perempoean-perempoean jang menjanji. Pada waktoe itoe soerak itoe disertakan kajaka dan kakala. Dalam menjanji itoe perempoean selaloe memoedji berhalanja dan dewadewa jang kelilingnja. Dan dimintanja soepaja padi itoe diperbanjakkan sekali, sebagai orang menimba air dari mata air. Diminta soepaja padi sebagai orang menimboen pasir adanja.

Sekarang ini perloe doea orang imam. Jang pertama sembahjang di Katoda Woka dan jang lain di kepala tikar. Kalau padi itoe soedah diirik, moela-moela haroes sembahjang di Katoda Kawindoe. Jaitoe persembahkan persembahan makanan. Disediakan satoe tempoeroeng nasi dan hati ajam. Sembahjangnja begini :

„Makan dan minoemlah hai ilah jang melindoengi kami, sekarang ini padi itoe soedah diirik, biarlah padi itoe diperbanjakkan sangatsangat, sehingga sebagai orang jang mengangkat pasir atau sebagai orang jang menimba air dari mata air. Koeminta kiranja ilah menjoeroeh hamba-hambamoe akan pergi merampas dan merampok kepada padi-padi jang berkeliling dan himpoenkanlah disini djoea. Soepaja

D1. 98. 
namakoe boleh termasjhoer kemana-mana djoea adanja. Terimalah permintaankoe!"

\section{d. Menjimpan.}

Orang-orang jang bersembahjang di Katoda Woka moelai bersembahjang, djoega di kepala tikar pengirik orang bersembahjang djoega, sehingga habis padi itoe diangkat dan diisi dalam dandak.

Baiklah dengarlah doeloe akan sembahjangnja di Katoda Woka. Pada tempat itoe dipersembahkan doea piring nasi dan sebahagian hati dan djantoeng babi dan djoega leher dari babi tadi (jang masih mentah). Imam itoe bersembahjang begini :

„Makan dan minooemlah ja ilah, karena telah koesadjikan nasi dan djantoeng dan hati babi bagimoe, karena padi itoe soedah habis diirik, biarlah padi itoe diperbanjakkan sangat, sehingga sebagai orang jang menimba air dari mata air adanja. Koeharaplah segala hambahambamoe akan disoeroeh olehmoe akan pergi mengoempoelkan padi pada sekeliling tempat ini, dan himpoenkanlah disini, soepaja padikoe boleh bertimboen-timboen adanja. Soepaja namakoe boleh dipoedji berkeliling."

Hal ini (hal sembahjangnja) dioelang-oelangnja sampai padi itoe habis diangkat dan diisi dalam dandak. Habis diangkat semoea, baharoe imam itoe toetoep sembahjangnja, katanja: ,Terimalah permintaankoe!"

Pada kepala tikar dipersembahkan: 2 piring nasi, hati dan djantoeng babi dan djoega leher babi jang mentah. Perkataan sembahjangnja sama sadja dengan perkataan orang jang bersembahjang di kepala tikar. Boleh dikatakan sama sadja ta' ada bedanja apa jang diboeat oleh jang pertama.

Kemoedian imam-imam itoe membahagi nasi persembahan itoe kepada anak-anak jang dekat, tetapi leher babi jang mentah itoe bahagian imam-imam itoe. Sesoedah itoe perempoean-perempoean pembahagi nasi moelai membahagi nasi djoega dan laki-laki pembahagi daging membahagi daging-daging itoe kepada jang datang. $\mathrm{Hal}$ bahagi pada waktoe itoe diberi dengan kelimpahan, sehingga orangorang itoe masih sisakan oentoek dibawa keroemahnja. Hanja orangorang besar-besar (radja-radja) masih dihantarkan beras dan daging jang mentah keroemahnja. Waktoe semoea orang soedah makan, orang-orang jang hadir dibagi sirih pinang lagi.

Sesoedah semoea hal itoe, padi tadi jang masih bertjampoer dengan kotoran (sampah-sampah) atau ampas, ditjeraikan (namanja patimboeng). Waktoe soedah patimboeng padi itoe diisi dalam loemboeng 
atau dandak. Waktoe diisi dalam loemboeng, imam bersembahjang pada moeloet loemboeng (dandak) itoe. Maksoednja soepaja padi itoe djangan lekas kehabisan. Sembahjangnja begini:

„Makanlah sirih dan pinang, sebab saja soedah toetoep loemboeng ini, biarlah padi ini djanganlah lekas kehabisan, sebab itoe saja persembahkan padamoe seekor ajam dan sepotong kawadak. Akan tanda ilah terima biarlah oera manoe ini memberi tanda jang baik kepadakoe. Terimalah permintaankoe!"

Soedah itoe ajam itoe disembelih laloe dibakar. Sesoedah dibakar dan dibelah diperiksa oera ajam itoe. Hati ajam itoe dibakar sadja. Kalau soedah masak hati ajam itoe imam bersembahjang lagi. Diminta soepaja ilah makan dan minoem. Lain tidak hanja permintaannja dioelangnja sadja.

Kemoedian beberapa boelan, kalau padi itoe hendak diboeka dandak itoe, imam bersembahjang lagi dengan persembahan seekor anak ajam dan sepotong kawadak dan satoe tempat sirih pinang. Katanja:

„Makanlah sirih dan pinang hai ilahkoe, biarlah padi ini djangan mengadakan penjakit didalam toeboeh kami, melainkan akan memberi kekoeatan bagi kami. Dan koeminta djanganlah padi itoe lekas kehabisan, sebab itoe saja memberikan padamoe seekor anak ajam ini dan sepotong kawadak ini. Akan tanda jang ilah terima biarlah oera manoe ini memberi tanda baik kepadakoe. Terimalah permintaankoe!"

Soedah itoe diboenoeh ajam itoe dan dibakar dan dibelah dan diperiksa hatinja. Anak ajam itoe dibakar. Sesoedah masak imam itoe sembahjang lagi, jaitoe persembahkan daging ajam itoe. Pada waktoe itoe diminta soepaja ilah makan. Lain ta' ada hanja dioelangnja sadja perkataan sembahjangnja jang pertama kali.

Hal hasil keboen jang lain, seperti djagoeng, katjang d.I.1. ta' perloe bersembahjang adanja.

Begitoelah halnja berkeboen ditanah Rakawatoe!

\section{AANTEEKENINGEN.}

1) De term ,kabanda” slaat op de Soembaneesche wijze van grondbewerking. Een aantal mannen en vrouwen, meestal vier tot zes, staan op een rij in het veld. $\mathrm{Zij}$ hanteeren ieder een tweetal zware stokken, die zij tegelijk met kracht tegen den grond stooten. Daarna heffen zij hun stokken weer op en laten deze op dezelfde plaatsen 
opnieuw stooten. Zijn de gaten, die hierbij ontstaan, diep genoeg, dan halen zij tegelijk alle stokken schuin naar beneden, zoo dat door de punten der stokken, die in den grond steken, een plag van ongeveer een voet breed uit den grond wordt omgelegd. Daarna maken zij hun stokken los en herhalen de bewerking vlak er naast. Zoo gaan zij door tot de geheele tuin is gekeerd. Een tuin, die pas de kabanda-bewerking heeft ondergaan, ziet er eenigszins uit als een geploegd veld. De voren zijn evenwel veel minder regelmatig. Het is een zwaar werk; de resultaten van het keeren kunnen met die van ploegen worden vergeleken.

2) „Amabokol hamajang”. Het eerste deel van deze samenstelling beteekent familie-oudste, letterlijk ,groote vader". De lieden, die zoo worden genoemd, zijn de hoofden van de kabisoe (vaderzijdige traditioneele verwantengroep) in de stamdorpen. Het tweede gedeelte beteekent "offeren”. Het is dus een dorpsoudste, die voor het offeren zorgt.

3) „Poei mowal” is een wicheltouw, dat ieder orthodoxe Soembanees weet te hanteeren en liefst in zijn sirihtasch altijd bij zich draagt. Het gebruik van dit voorwerp is een der meest gewone wijzen van wichelen. Uitvoerig worden we over dit instrument ingelicht door Wielenga in de „Macedoniër”, jaargang XII, 1908, p. 14 e.v.

4) Het onderzoeken van kippendarmen is een gebruik, dat heet aan te geven, hoe de bovenaardsche machten een bepaalde handeling, speciaal een offerhandeling, appreciëeren.

5) „Kawadak” is een dun schilfertje edel metaal, meestal goud of wel een alliage van goud en zilver. Soms is het vormloos, soms heeft men er den vorm van een zonnetje of rozetje aan gegeven. Het dient als offergave in vele der ontelbare offers, die in het Soembaneesche leven worden gebracht. Vele Soembaneezen dragen er altijd een of enkele van bij zich, daar men nooit weet wanneer men voor eenig doel een klein offer zal moeten brengen.

6) „Katoada woka” is de katoada (katoda), de offersteen, van den tuin (woka), de plaats waar men den geest, die den tuin beheerscht, gunstig kan stemmen.

7) „Padira tana” zijn de grenzen van den tuin, die ook in een offersteen (katoda) worden aanbeden.

8) „Roemah berhala” gebruikt de schrijver voor de rertaling van 
het Soembaneesche ,oemah marapoe”. Deze marapoe-huizen liggen in het stamdorp, op den praing, meestal op een heuvel of een ander hooggelegen, ongenaakbaar punt gebouwd. In het stamdorp heeft elke kabisoe, die in dat dorp thuis hoort, een of meer huizen, die allen roemah marapoe zijn. In die huizen wordt het grootste deel van het ritueel volbracht. Het is de bewaarplaats van het voornaamste kabisoeheiligdom en woonplaats van den kabisoe-god, de marapoe.

9) „Berhala jang berfamili dengan berhalanja”, zijn naar Soembaneesche opvattingen de marapoe van de kabisoe, waarmede de egokabisoe familie-relaties onderhoudt. Zooals de leden van verschillende kabisoe, die tot elkaar in een vaste huwelijksrelatie staan, familie van elkaar zijn, worden ook gedacht hun goden op dezelfde wijze verwant te zijn.

10) De plaats, waar de voorouders (ook ,marapoe” geheeten) op aarde zijn gekomen en mensch zijn geworden. De meeste kabisoe weten deze plaats voor hun geslacht nauwkeurig aan te geven.

11) Ik vestig de aandacht er op, dat alle hemelsche verwanten van de ego-groep in het ritueel worden aangeroepen. Zooals voor het voortbestaan der aardsche familie-groep de relatie's met andere dergelijke groepen noodig zijn in sociaal verkeer, vooral tot uiting komend bij de huwelijkssluiting en in de door de traditie geijkte wegen, die het economische goederenruilverkeer pleegt te volgen, is de herdenking der relaties met de hemelsche verwanten noodig voor het welslagen van de tuinbewerking.

12) Hier wordt onderscheid gemaakt tusschen offers aan de afgoden en aan de zielen der afgestorvenen. Beiderlei soort bovenaardsche wezens worden ,marapoe” genoemd. De eerste, meestal de kabisoe-goden, heeten de levende marapoe, de zielen der overledenen zijn de doode marapoe. Toch worden de levende marapoe ook als voorouders gekend. Het verschil tusschen deze soorten ligt in de mythologie, waarin van de kabisoe-marapoe sprake is en niet van de overleden verwanten zonder meer. Deze laatste plegen geen rol in de mythologie te spelen en zijn daarom van minder belang.

13) „Katoda kawindoe” is de offersteen, die den buitenkant van het huis bewaakt. Niet geheel juist noemt Iaha deze katoda de beschermer van het erf. Meestal toch hebben de Soembaneesche huizen geen eigen erf, maar staan zij vrij in het dorp of in de tuinvlakte.

14) „Kaheli bokoel” heet de voornaamste plaats van het huis. Als 
men een Soembaneesche woning door de rechter deur binnengaat komt men in het officieele gedeelte, rechts van den haard, bij den voornaamsten huispaal. Tegenover dezen huispaal tegen den rechter zijwand is een verhoogd gedeelte van den vloer, waar tijdens offerhandelingen de zitplaats der gasten is. Dit heet de kaheli bokoel (groote vloer).

15) „Mamoeli” is de bekende Soembaneesche traditioneele ,oorversiering", waarvan de vorm volgens sommigen aan den vorm van het vrouwelijk schaamdeel is ontleend. Bij geschenken met een sociaal karakter worden altijd eenige mamoeli gegeven. $\mathrm{Zij}$ hebben daarbij een waarde, die ver boven hun intrinsieke metaalwaarde uitgaat. Sommige modellen zijn zeer in aanzien en mogen alleen door vorsten worden bewaard. Zij worden van goud, zilver of koperlegeering gemaakt.

16) „Kanatar” is de tegenhanger van de mamoeli. Het is een van dun metaaldraad gevlochten keten, aan welks eene einde, soms ook beide einden, de vorm van een slangenkop is gegeven. Als de mamoeli als iets vrouwelijks moet worden opgevat, is de kanatar (mooie gouden exemplaren heeten „loeloe amahoe”) de mannelijke tegenhanger.

17) „Lakoe loeloeng” is een vorm van kanatar.

18) „Laoe komboe” is een vrouwensarong met ingeweven figuren. Laoe is in het algemeen het vrouwenkleedingstuk, de sarong. Komboe wijst op de aanwezigheid van figuren.

19) De woorden ,baik loteng baik geladaknja” zijn mij niet duidelijk. De gewone verblijfplaats der bovenaardsche wezens is de vliering boven den haard. Soms dalen zij wel eens af op een rakje rechts boven de deur gehangen (jarang) om er getuige te zijn van besprekingen tusschen de menschen. Dit kan echter bezwaarlijk met het gebruikte ,geladak" worden aangegeven. Loteng slaat zeker op de zolder boven den haard. Misschien moet geladak als een dubbel hiervan worden opgevat.

20) „Kajaka” beteekent schreeuwen, juichen. De Soembanees roept daarbij ook kajaka; het is dus zoo iets als ons hoera roepen. 